\title{
Adult Heart Disease due to the Coxsackie Virus Group B ${ }^{\star}$
}

\author{
W. G. SMITH \\ From Sir Charles Gairdner Hospital, Perth, Western Australia
}

Myocarditis, until lately out of favour, is again becoming an acceptable diagnosis. The myocardium can be attacked by many organisms such as bacteria, viruses, fungi, rickettsiæ, spirochætes, and parasites. Viruses are of special importance, and acute or chronic myocarditis has been occasionally described in such viral infections as measles, mumps, poliomyelitis, infectious mononucleosis, psittacosis, rabies, varicella, variola, lymphocytic choriomeningitis, influenza, Coxsackie infections, infective hepatitis, yellow fever, and epidemic hæmorrhagic fever (Woodward et al., 1960). The Coxsackie group $B$ viruses are now increasingly recognized as a relatively frequent cause of myocarditis with or without pericarditis.

The Coxsackie virus was named by Dalldorf (1949), who isolated it in 1948 from the stools of two paralysed children who lived in the small town of Coxsackie, near New York. Today the Coxsackie genus of viruses comprises Group A and Group B, containing 24 and 6 types, respectively. These groups have similar physical and biological properties, but differ in their clinical effects in man and animals. The two groups can be separated by their different effects in susceptible animals, especially the neonatal suckling mouse. Group A viruses cause a diffuse skeletal myositis and flaccid paralysis, often with herniation of the abdominal wall. Group B viruses cause a patchy myocarditis, focal skeletal necrosis, tremors, and spastic paralysis. These features are often associated with encephalomyelitis, hepatitis, and pancreatitis. The essential difference is the production of myocardial lesions by the Group B viruses.

Coxsackie viruses are world wide, and are frequent causes of upper respiratory tract infection, gastroenteritis, and other clinical syndromes. Curnen,

Received February 1, 1965.

* This paper formed the basis of a communication to the Thoracic Society of Australia in Sydney, in October 1964.
Shaw, and Melnick (1949) noted the probable association with epidemic pleurodynia (Bornholm disease), and this was confirmed the following year (Kilbourne, 1950).

Human infections with Group A viruses include herpangina, febrile upper respiratory tract infection, aseptic meningitis, and a paralytic disease similar to poliomyelitis. Some patients develop a rubelliform skin eruption with fever. In humans, Group B viruses cause epidemic myalgia or pleurodynia (Bornholm disease), myocarditis, pericarditis, aseptic meningitis, orchitis, exanthemata, and a syndrome of lymphadenopathy and splenomegaly. For practical purposes it can be accepted that the heart lesions in man are due to Coxsackie $B$ viruses, though an $A$ virus has been recovered from the stools of newborn infants with myocarditis and pericarditis (Hosier and Newton, 1958; Movitt et al., 1958). The latter finding is of doubtful significance in view of the widespread nature of the $A$ virus and the lack of confirmatory antibody tests.

Coxsackie B myocarditis in neonatal infants was first reported from Southern Rhodesia in 1955 (Montgomery et al.), and Southern Africa in 1956 (Javett et al.). Similar small nursery epidemics were then reported from other parts of the world, including Amsterdam (van Creveld and de Jager, 1956). The disease was frequently fatal, and some of the infants showed features similar to those in experimental animals, such as hepatitis, nephritis, pancreatitis, and encephalomyelitis. Most of the earlier cases occurred at a time when Coxsackie virus infections were prevalent in the general community, but it has since been pointed out that the diagnosis should not be ignored in a nonepidemic period (Hosier and Newton, 1958).

The first reports of Coxsackie heart disease in adults appeared in 1957, when Fletcher and Brennan from Northern Ireland reported an adult male with pericarditis due to a Coxsackie B4 virus. 
TABLE

COXSACKIE PERICARDITIS

\begin{tabular}{|c|c|c|c|c|c|c|c|c|c|c|c|c|c|}
\hline Case No., & age & and sex & $\begin{array}{l}\text { Dura- } \\
\text { tion } \\
\text { of } \\
\text { symp- } \\
\text { toms }\end{array}$ & $\begin{array}{l}\text { Family } \\
\text { illness }\end{array}$ & $\begin{array}{l}\text { Chest } \\
\text { pain } \\
\text { (peri- } \\
\text { cardial) }\end{array}$ & Fever & $\begin{array}{c}\text { Peri- } \\
\text { cardial } \\
\text { rub }\end{array}$ & ESR & $\begin{array}{c}\text { Radio- } \\
\text { graph } \\
\text { (heart } \\
\text { size) }\end{array}$ & $\begin{array}{l}\text { Electro- } \\
\text { cardi- } \\
\text { gram }\end{array}$ & $\begin{array}{c}\text { Cox- } \\
\text { sackie } \\
\text { neutral } \\
\text { antibody } \\
\text { titre }\end{array}$ & $\begin{array}{l}\text { Virus } \\
\text { culture }\end{array}$ & Outcome \\
\hline 1 & 30 & $\mathbf{M}$ & $2 \mathrm{mth}$. & + & + & + & $10^{+} \mathrm{dy}$. & + & ++ & $\mathbf{T}$ & $\begin{array}{l}\text { B5 } \\
1 \text { in } 32 \\
1 \text { in } 64\end{array}$ & - & $\begin{array}{l}\text { Recovery } \\
3 \text { wk. }\end{array}$ \\
\hline 2 & 42 & $M$ & 1 dy. & + & + & + & $2 \stackrel{+}{d y}$ & + & Normal & ST & $\begin{array}{c}\text { B5 } \\
1 \text { in } 20 \\
1 \text { in } 80\end{array}$ & - & $\begin{array}{l}\text { Recovery } \\
2 \text { wk. }\end{array}$ \\
\hline 3 & 33 & $M$ & 9 dy. & - & + & + & $6 \stackrel{+}{d y}$ & + & $\stackrel{+}{\text { (slight) }}$ & ST & $\begin{array}{c}\text { B5 } \\
1 \text { in } 1024 \\
1 \text { in } 1024\end{array}$ & B5 & $\begin{array}{l}\text { Recovery } \\
3 \text { wk. }\end{array}$ \\
\hline 4 & 40 & $M$ & 9 dy. & 一 & + & + & - & ? & $\stackrel{+}{+}$ & $\mathbf{T}$ & $\begin{array}{l}\text { B5 } \\
1 \text { in } 40 \\
1 \text { in } 40\end{array}$ & - & $\begin{array}{l}\text { Recovery } \\
5 \text { wk. }\end{array}$ \\
\hline 5 & 56 & $\mathbf{M}$ & $8 \mathrm{hr}$. & + & + & + & $8 \mathrm{hr}$. & + & Normal & ST & $\begin{array}{c}\text { B2 } \\
1 \text { in } 40 \\
1 \text { in } 40\end{array}$ & - & $\begin{array}{c}\text { Recovery } \\
2 \text { wk. }\end{array}$ \\
\hline 6 & 29 & $\mathbf{M}$ & $7 \mathrm{dy}$. & - & + & + & $?$ & + & Normal & ST & $\begin{array}{l}\text { B4 } \\
1 \text { in } 160 \\
1 \text { in } 160\end{array}$ & - & $\begin{array}{l}\text { Recovery } \\
3 \text { wk., but had } \\
4 \text { recurrences } \\
\text { in following } 2 \\
\text { yr. }\end{array}$ \\
\hline
\end{tabular}

In the same year from the United States, Weinstein (1957) reported an adult male patient with pericarditis due to Coxsackie B5. In 1958, Fletcher and Brennan reported a further male patient with pericarditis due to a B3 virus. Null and Castle (1959) reported three adult patients with myocarditis and pericarditis due to Coxsackie B5 viruses. Subsequently scattered reports of other adult patients with Coxsackie myocarditis and pericarditis have been published (Bell and Meis, 1959; Agranat, 1961; Glajchen, 1961; Johnson et al., 1961; Lane, 1961; Lewes and Lane, 1961; Swann, 1961 ; Pollen, 1963). It is very likely that such reports will multiply rapidly in the next few years with increasing awareness of the disease, and availability of virus reference laboratories.

"Idiopathic non-specific benign pericarditis" is not an uncommon condition and has been recognized since 1854 (Christian, 1951). There are several causes including chest wall trauma, systemic lupus erythematosis, heart operations, allergy, and irradiation. The association with Bornholm disease was noted 30 years ago (Bing, 1933; Aagaard and Jensen 1952). It is now apparent that the most frequent cause is a Coxsackie B virus (Bradley, 1964). It is also recognized that the condition is hardly ever restricted to the pericardium; the myocardium is frequently, if not always, involved, and this indeed is the cause of the electrocardio- graphic changes (Wolff and Grunfeld) 1963). Other serous membranes, especially the pleura, may be affected. The term "benign" may be inappropriate in view of the associated myocarditis, and the occasional complications reported. A more accurate and descriptive term would be "Coxsackie myo-pericarditis".

Ten adult patients with heart disease, believed to be due to Coxsackie viruses, are reported. Six had the syndrome of "acute benign pericarditis", and presented with chest pain suggestive of pericarditis and mimicking myocardial infarction. The main details of these patients are shown in the Table. The remaining patients had evidence of myocarditis without associated pericarditis.

\section{CASE Histories}

Case 1. A labourer, 30 years old, previously healthy, was admitted to the Sir Charles Gairdner Hospital on March 20, 1962. Three months before admission he began to have light-headedness and febrile headaches. Clinical examination by his family doctor was negative. A blood count was normal, and the patient recovered after three weeks.

One month later he had intermittent pain in the right iliac fossa, and wondered about the possibility of appendicitis. Three weeks before admission, he developed sudden pain in the left shoulder, root of the neck, and upper substernal region. This was aggravated by 


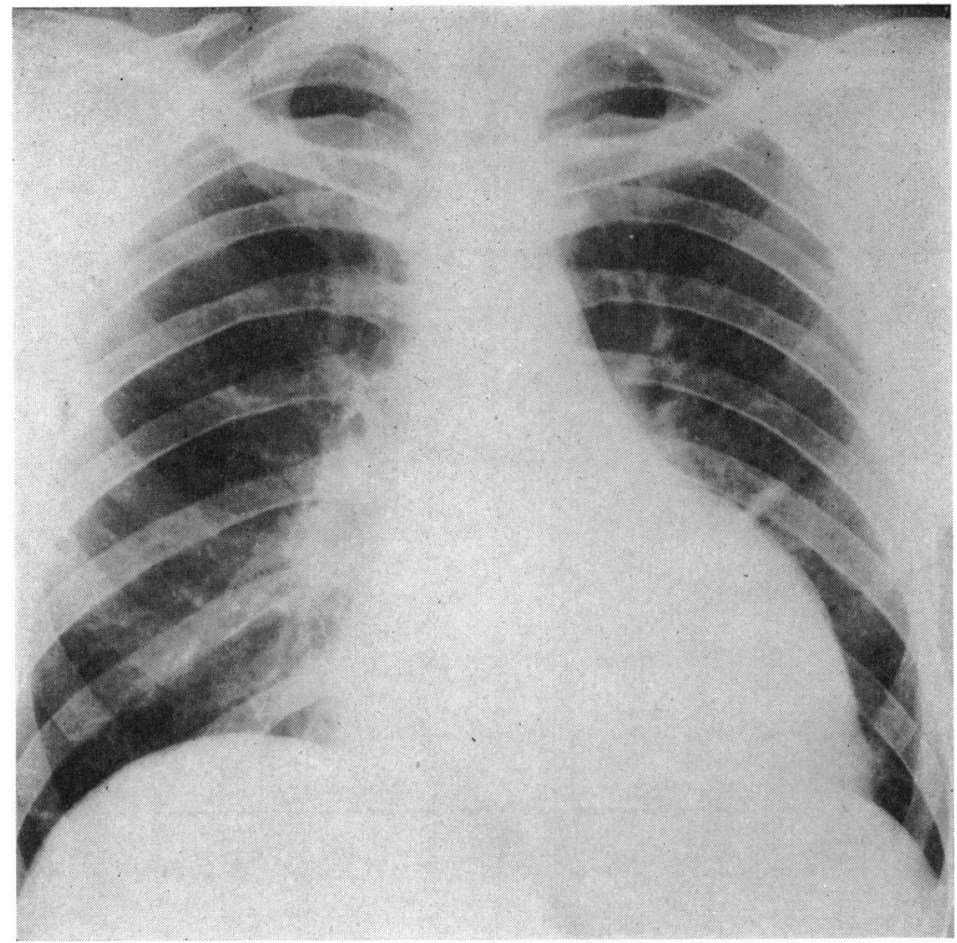

FIG. 1.-Chest radiograph of Case 1, showing enlarged shadow with streaky infiltration in left mid-zone.

lying flat and deep breathing and, sometimes, by swallowing. He gave no history of upper respiratory tract infection, sore throat, skin rash, or muscle pain, but felt febrile. During the week before his admission to hospital, two of his four children had been running a low-grade fever associated with malaise.
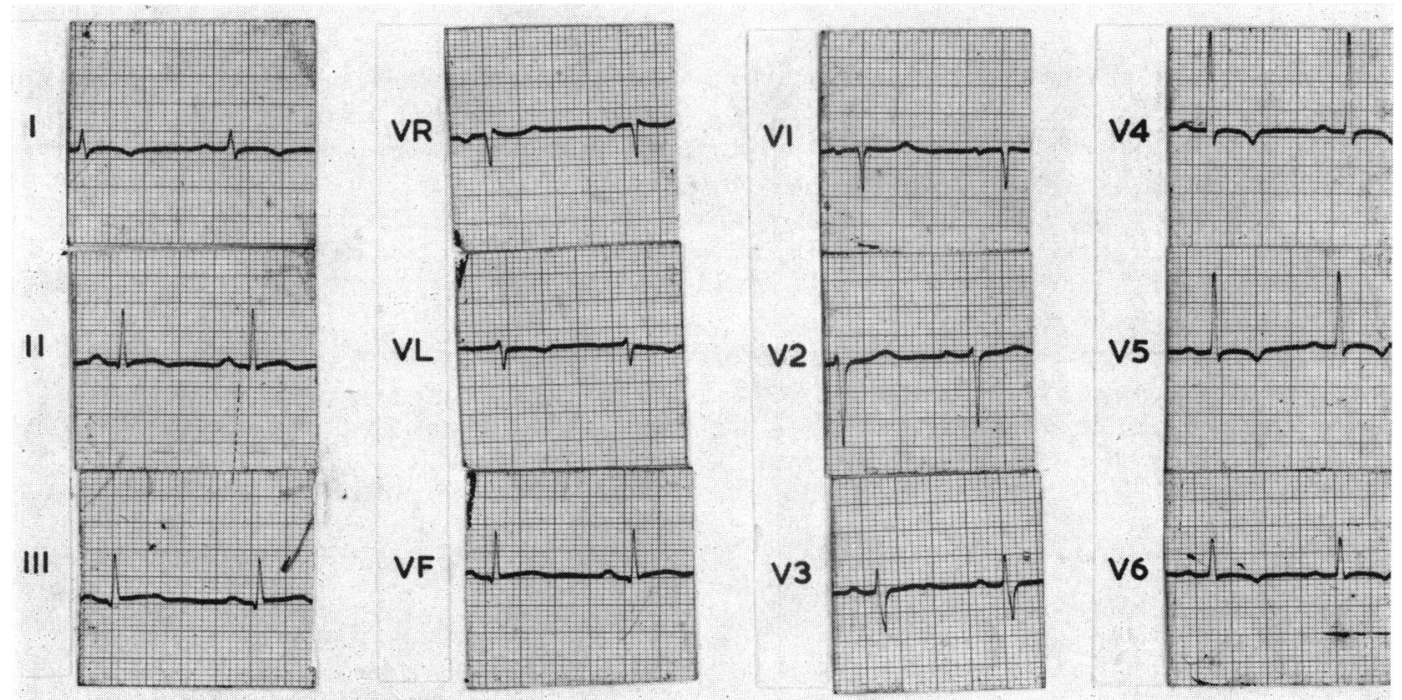

FIG. 2.-Electrocardiogram (April 10, 1962) of Case 1 showing widespread $T$ wave inversion. 
On admission the temperature was $38^{\circ} \mathrm{C}$. His general condition was good, but he was slightly breathless and orthopnœic. The jugular venous pressure was slightly raised. There was no paradox of the jugular venous or arterial pulse. Blood pressure was $125 / 80 \mathrm{~mm}$. Hg. The cardiac impulse was felt in the fifth space on the anterior axillary line. In the præcordium there was a widespread pericardial friction rub with pleuropericardial element. There were fine crepitations at both lung bases and a few small axillary nodes were felt.

The urine was normal. Chest radiograph (Fig. 1) showed considerable enlargement of the heart shadow with patchy infiltration in the left middle and lower zones. The first electrocardiogram was normal, apart from slightly low voltage. Daily records after April 1 showed progressive $T$ wave inversion in V3, 4, 5, and 6 , and in most other leads (Fig. 2). The $P$ waves were slightly bifid and a few ventricular ectopic beats were present in one tracing. Urine was negative. The hæmoglobin was $13.1 \mathrm{~g} . / 100 \mathrm{ml}$; t total white cell count 10,000 c.mm. with normal proportions; ESR $39 \mathrm{~mm}$. in one hour (Westergren). Serum transaminase (SGOT) was 32 units and lactic dehydrogenase (LDH) 310 units. ASO normal and C-reactive protein negative. Viral studies were performed; no cytopathic agent was isolated from the stool or throat. The neutralizing antibody titre against Coxsackie B5 was 1 in 32 on March 22 and 1 in 64 on April 1. Titres against the other $B$ viruses were less than 1 in 8 . His two sick children showed rising antibody titres against Coxsackie B5 in paired blood samples, the final readings being 1 in 256.

During his first ten days in hospital he had intermittent fever up to $39.5^{\circ} \mathrm{C}$. Thereafter he was apyrexial and had no special treatment other than bed-rest and paracetamol. Pericardial aspiration was attempted on March 24, using the apical route. No pericardial fluid was obtained, though the left ventricular cavity was entered with a fine needle. The pericardial rub gradually disappeared over about 10 days and, as the rub became fainter, a temporary third heart sound was audible. No heart murmurs were present at any stage and the heart sounds were easily audible throughout. On discharge, 22 days after admission, his ESR was normal. The chest radiograph showed a normal heart size with clear lung fields (Fig. 3), and the electrocardiogram was also normal (Fig. 4). At his outpatient visits in August 1962 and June 1964, he was perfectly well and had no recurrence of similar symptoms. Chest radiograph and electrocardiogram were again normal.

Summary. A 30-year-old man presented with a three-week history suggestive of pericardial or left pleural pain. He had an extensive pericardial rub and moderate pyrexia. The heart was considerably increased on the chest radiograph. The electrocardiogram and other features indicated that the heart enlargement resulted from myo-pericarditis, without significant

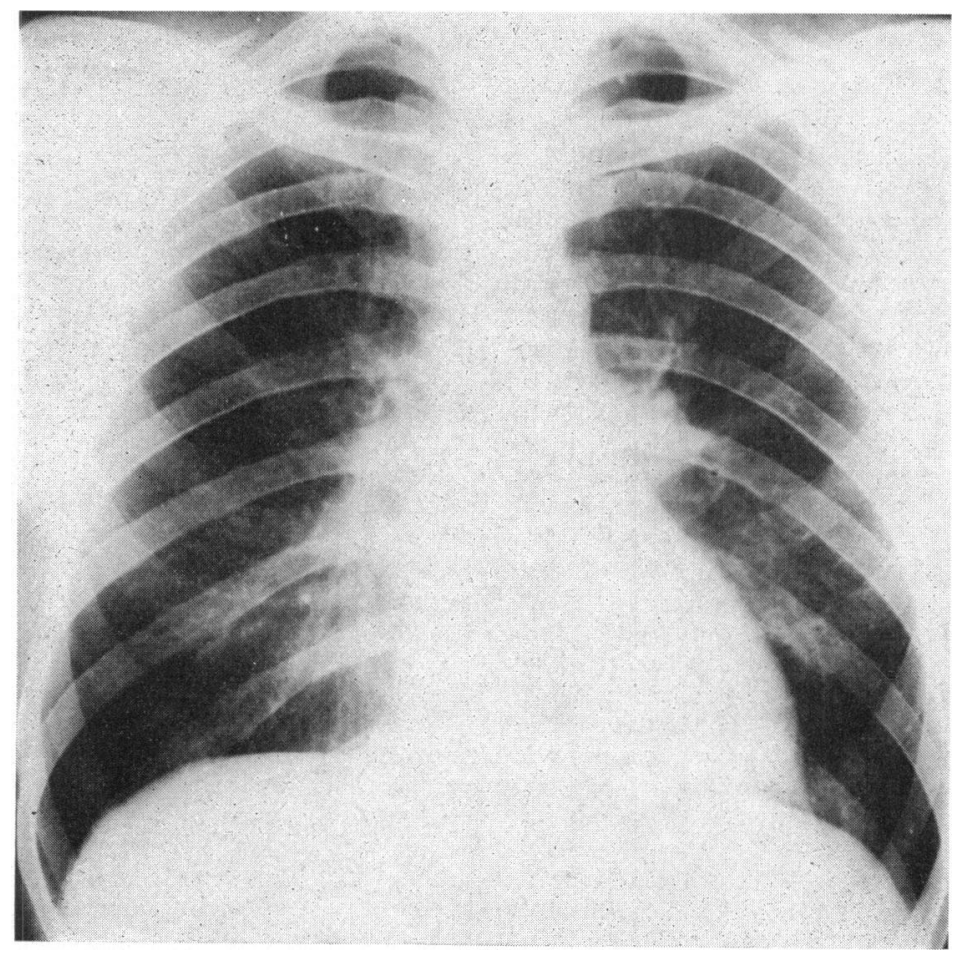

FIG. 3.-Chest radiograph of Case 1 (now normal). 


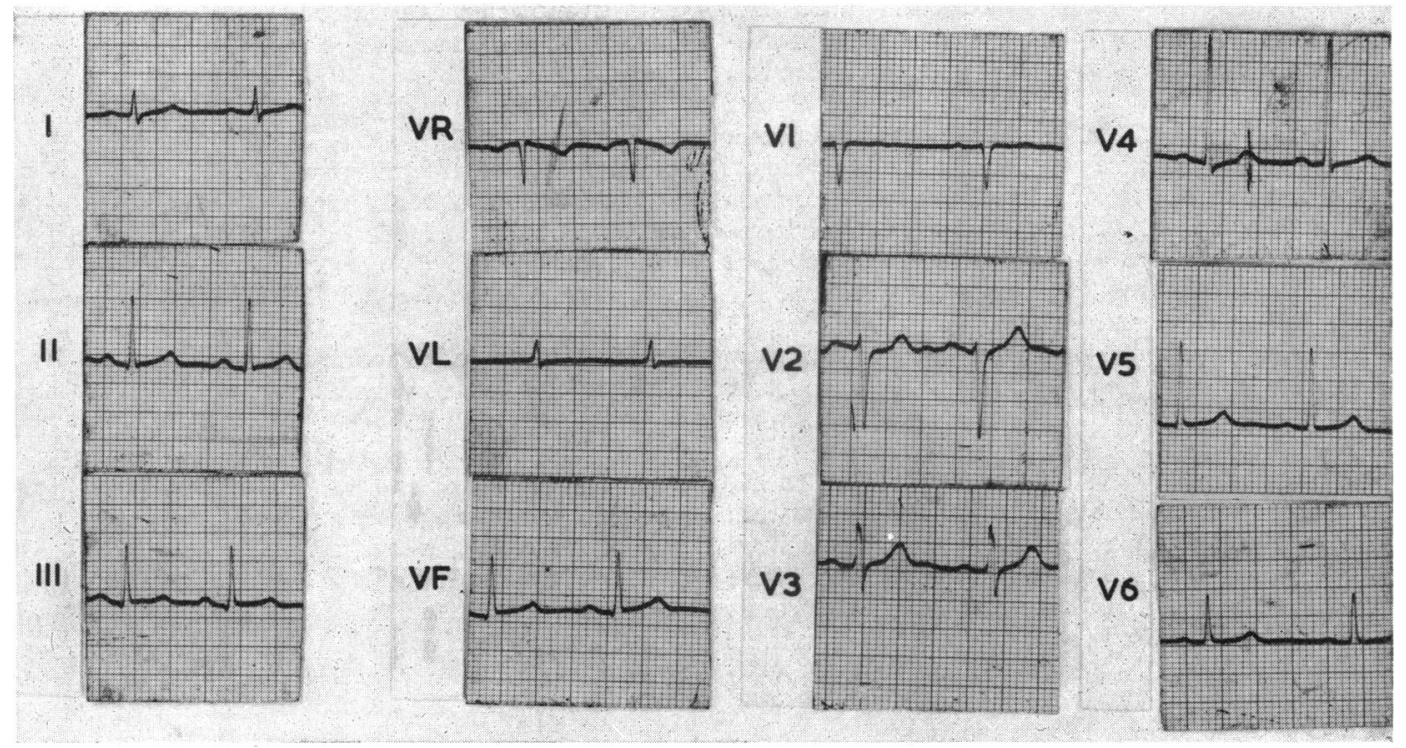

Fig. 4.-Electrocardiogram (May 22, 1962) of Case 1 (now normal).

pericardial effusion. A significant neutralizing antibody titre against Coxsackie B5 was found. Two of his children, who had recently been ill, had high titres against the same virus. He made a complete recovery in about three weeks, and had no recurrence of symtpoms.

Case 2. A tractor driver, 42 years old, was admitted to the University Department of Medicine, Royal Perth Hospital, on February 8, 1964. On the day before admission he developed an aching epigastric discomfort, later moving into the retrosternal region and the medial aspect of both arms. This was aggravated by lying flat and on taking a deep breath. He had no influenzal symptoms and had previously been quite well. His wife and daughter were suffering from an upper respiratory infection at the time of admission to hospital.

On admission his condition was good, though he had pain on breathing particularly on lying flat. Temperature was $37 \cdot 9^{\circ} \mathrm{C}$. The venous and arterial pulses were normal. Blood pressure was $130 / 85 \mathrm{~mm}$. Hg. The left ventricle was easily felt. There was no pericardial friction, cardiac bruit, or evidence of heart failure. The urine, hæmoglobin, and white cell count were normal. ESR $22 \mathrm{~mm}$. in one hour (Westergren). Serum transaminase (SGOT) readings at two-day intervals were 23,40 , and 44 units, respectively. Chest radiograph showed no abnormality. The initial electrocardiogram (Fig. 5) showed slight ST elevation in leads I, II, VL, and V3, 4, 5, and 6. Two days later the ST elevation was more marked and the ST segment was concave upwards. The ASO titre was normal and the C-reactive protein test was negative. No cytopathic agent was found in the throat or fæces, but he showed an initial neutralizing antibody titre against Coxsackie B5 of 1 in 20, and this had risen 8 days later to 1 in 80 . The titres against the other B viruses were less than 1 in 10.

A fairly extensive pericardial rub was audible on the day after admission and persisted for 48 hours. His chest radiograph remained normal. On discharge home five days after admission his cardiogram had improved and his pain was absent. At an out-patient visit one week later he was well and the record was entirely normal (Fig. 6.)

Summary. A 42-year-old man presented with a 24hour history suggestive of pericarditis. Two members of his family had recently suffered an upper respiratory tract infection. A fairly widespread pericardial rub appeared on the day after admission and the electrocardiogram showed evidence of acute myopericarditis. A significant neutralizing antibody titre against Coxsackie B5 was obtained. The patient made a complete clinical and electrocardiographic recovery in two weeks.

Case 3. A male machinist, 33 years old, was first referred to a colleague on May 1, 1962. He gave a history of substernal discomfort of nine days' duration. This was worse towards the end of the day and was aggravated by effort, deep breathing, and lying flat. He gave no history of any recent upper respiratory tract infection or influenzal symptoms, and there had been no family illness.

On examination his general condition was good. The temperature was $38^{\circ} \mathrm{C}$. The pulse was normal. Blood pressure was $140 / 80 \mathrm{~mm}$. Hg. There was no paradox of the jugular venous or arterial pulses. A loud pericardial rub was audible over the whole of the præcordium. The left ventricle was normally palpable. The lungs were clear and there were no other findings of note. Urine examination was negative. Hæmoglobin 16 g./100 ml., WBC 10,000 with 71 per cent neutrophil 


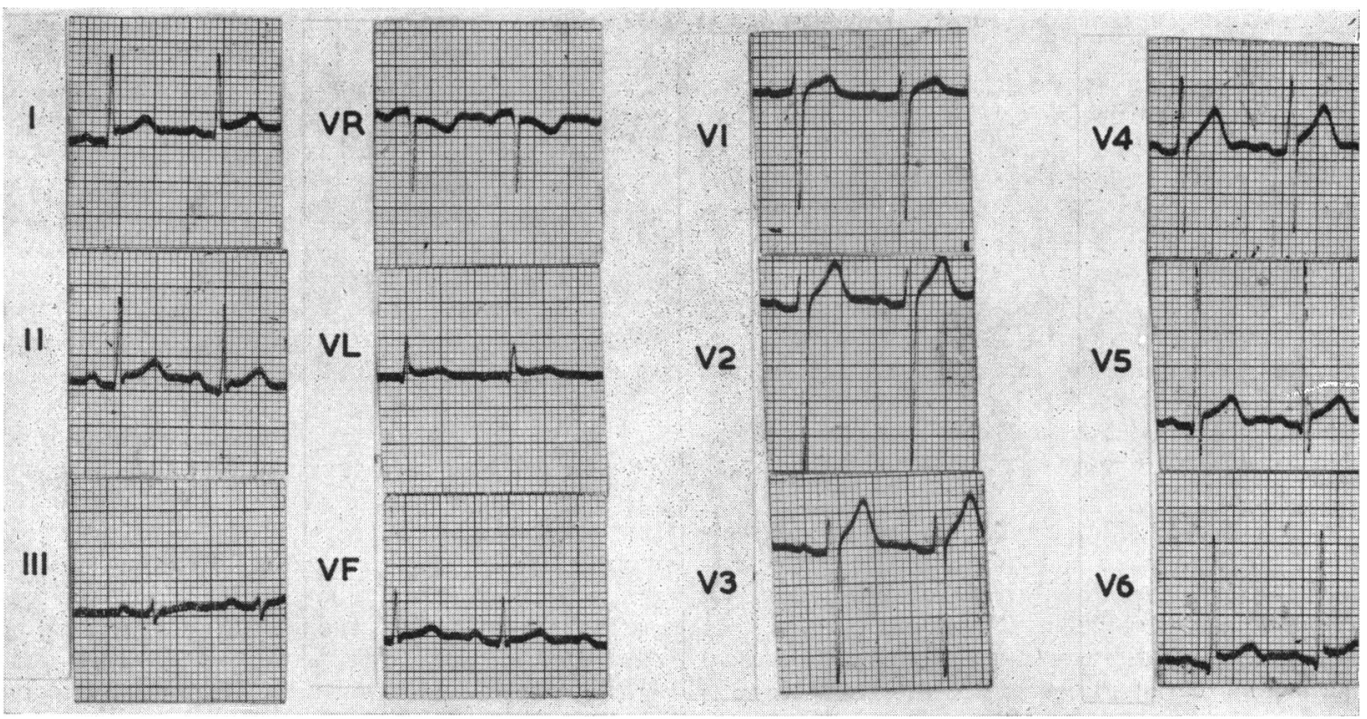

FIG. 5.-Electrocardiogram (February 6, 1964) of Case 2, showing ST elevation.

polymorphs, 23 per cent lymphocytes, 4 per cent monocytes, and 2 per cent eosinophils. ESR $60 \mathrm{~mm}$. in one hour (Westergren). Chest radiograph showed slight heart enlargement. Electrocardiogram showed sinus rhythm at 110 a minute. There was an rsR in lead III associated with slight $T$ wave inversion. The ST segment was elevated about $2 \mathrm{~mm}$. in leads I, II, VL, and V6.

The patient was admitted to hospital and received no special treatment other than aspirin and barbiturates.
Six days after admission he was apyrexial and his pain had disappeared. The pericardial rub was then inaudible and did not return. A repeat cardiogram showed that the ST segment was nearer the isoelectric line, but there was now inversion of $T$ in leads I, II, VF, V3, $4,5,6$, and 7 . A repeat white cell count showed a total count of 7,400 with 45 per cent neutrophils and 54 per cent lymphocytes. ESR was $64 \mathrm{~mm}$. in one hour (Westergren). Coxsackie B5 virus was isolated from the fæces and a very high titre of neutralizing antibody

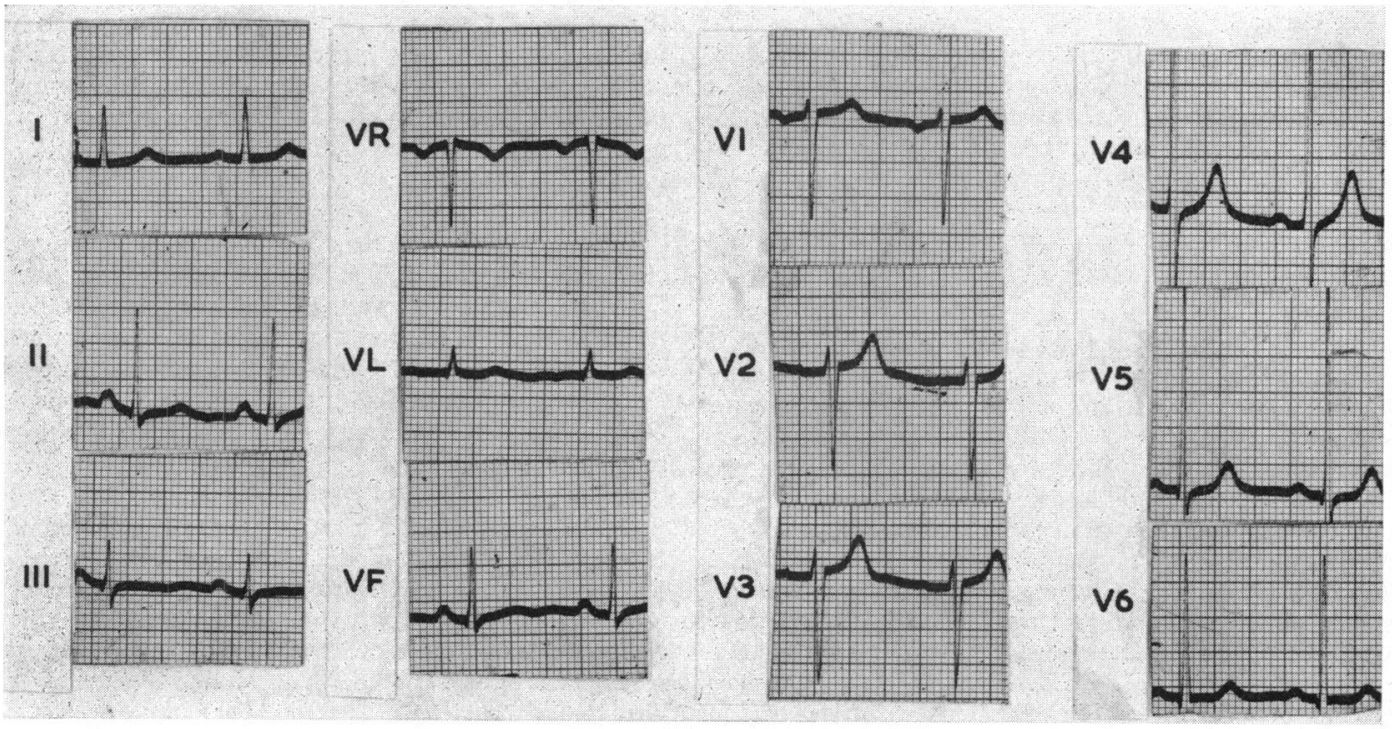

Fig. 6.-Electrocardiogram (February 19) of Case 2 (now normal). 
against this virus was obtained ( 1 in 1024 on May 4, and 1 in 1024 on June 7).

Sixteen days after admission the patient felt perfectly normal and there were no abnormal signs on examination. ESR was now $9 \mathrm{~mm}$. in one hour. The patient returned to work on June 5. The electrocardiogram at this time was almost normal apart from minimal $T$ wave changes in leads VF, V5, 6, and 7. He has remained entirely well since then.

Summary. A 33-year-old man was admitted with a nine-day history of substernal discomfort, suggestive of pericarditis. A widespread pericardial rub was present, and the elctrocardiogram showed evidence of myopericarditis. A very high antibody titre against Coxsackie B5 was present. He recovered in three weeks.

Case 4. A farmer, 40 years old, was first referred to a colleague on September 1, 1964. He gave a nine-day history of persistent severe substernal pain aggravated by deep breathing and lying flat. There was no history of any recent upper respiratory tract infection or influenzal symptoms and there had been no family illnesses. No pleural or pericardial rub was heard by the family doctor.

On examination there were no findings of note. Chest radiograph showed slight heart enlargement. The electrocardiogram showed flat $T$ waves in leads II, V3, and V4. The T waves were biphasic in V5 and 6. The ST segments were normal. There was a neutralizing antibody of 1 in 40 against B5 and less than 1 in 10 against the other $B$ viruses.

The patient was seen by the writer on October 5, eight weeks after his initial illness. He felt well and had had no chest pain for three weeks. Physical examination was negative. The electrocardiogram was still slightly abnormal, but the $T$ wave changes had improved since the initial tracing. The antibody titres were unchanged.

Summary. A 40-year-old man gave a three-week history of substernal pain suggestive of pericarditis. The cardiogram showed $T$ wave changes compatible with myo-pericarditis and a significant antibody titre against Coxsackie B5 was present. He recovered in three weeks.

Case 5. A labourer, 56 years old, was admitted to the University Department of Medicine, Royal Perth Hospital on April 7, 1964. He gave an eight-hour history of substernal pain aggravated by deep breathing. He had no influenzal symptoms, but stated that several family members had suffered from recent vomiting and diarrhœea.

On admission his condition was good. Temperature $37 \cdot 7^{\circ} \mathrm{C}$. There was a loud pericardial friction rub at the lower end and to the right of the sternum. There were no other findings of note. The white cell count and urine were normal. Chest radiograph was normal. Erythrocyte sedimentation rate $14 \mathrm{~mm}$. in one hour (Westergren). The electrocardiogram showed slight ST elevation in leads I, II, VL, V4, and 6. The T waves were slightly inverted in V5 and 6. There was a neutralizing antibody titre of 1 in 40 against Coxsackie
B2. The titre against the other $B$ viruses was less than 1 in 10 . Seventeen days later the titres were unchanged. The pericardial rub disappeared in eight hours and the patient rapidly lost his chest pain. Two weeks later he felt quite normal and had a normal electrocardiogram.

Summary. A 56-year-old man had an eight-hour history of chest pain suggestive of pericarditis. A loud, but transient, pericardial rub was present, and there were electrocardiographic features of acute myo-pericarditis. A significant titre against Coxsackie B2 was present. The patient made a complete clinical and electrocardiographic recovery in 2 weeks.

Case 6. A civil servant, 29 years old, first developed severe substernal pain aggravated by breathing, movement, and lying flat, in November 1962. He gave a history of a similar milder episode lasting a few days some months earlier. There was no preceding history of virus infection or family illness. He had moderate fever and an ESR of $29 \mathrm{~mm}$. in one hour (Westergren). The electrocardiogram showed slight ST elevation in leads II, III, VF, and V6. Three days later the ST segments were very elevated. The patient recovered in three weeks. The ESR was normal as was the electrocardiogram apart from $T$ wave flattening in I and V6.

The patient was well until April 1964 when he had a similar illness associated with pyrexia, slight neutrophil leucocytosis, and ESR $30 \mathrm{~mm}$. in one hour. The pain disappeared after two weeks. Two similar illnesses occurred in May and June 1964, and on both occasions a loud pericardial rub was present. During the June illness he was seen by a colleague, who confirmed the pericardial rub. The cardiogram again showed appearances very similar to those in $\mathbf{1 9 6 2}$. Chest radiograph was normal apart from a small right pleural effusion. Hæmoglobin and WBC normal. ESR $42 \mathrm{~mm}$. in one hour (Westergren). Antibody tests showed a titre of 1 in 160 against Coxsackie B4 and less than 1 in 10 against the other $B$ viruses. Ten days later the titres were unchanged. The patient was discharged free of pain after a week and by then the electrocardiogram had greatly improved. In October 1964 he was seen by the writer when he was well and had a normal record. He reported a mild recurrence of chest pain in September 1964.

Summary. A 29-year-old man had a history and electrocardiogram compatible with myopericarditis. The patient recovered in three weeks and was well until April 1964 when he had the first of four recurrences of chest pain, raised ESR, and electrocardiogram changes. He then had a fairly high titre against Coxsackie B4. On the last two occasions loud pericardial rubs were present.

Case 7. A business man, 30 years old, was admitted to the Sir Charles Gairdner Hospital on October 27, 1962. Three weeks before admission he developed an influenza-like illness with cough, rhinorrhœa, shivers, and severe generalized aches and pains. Some improvement followed penicillin and broad-spectrum antibiotics. Twenty-four hours before admission he suddenly became very breathless and slightly irrational. 
On admission he was pale, orthopnœic, cyanosed, and disorientated. His initial temperature was $37.5^{\circ} \mathrm{C}$., but it subsequently rose to $39 \cdot 2^{\circ} \mathrm{C}$. His pulse was $130 \mathrm{a}$ minute, regular and of rather poor volume. Blood pressure $168 / 80 \mathrm{~mm}$. $\mathrm{Hg}$. The heart was considerably enlarged and the left ventricle was easily palpable on the anterior axillary line in the sixth interspace. The sounds were well heard and there was a loud triple rhythm due to a third heart sound. There were no murmurs or pericardial rub at any stage. Jugular venous pressure was raised $3 \mathrm{~cm}$. above the sternal angle with the patient at $60^{\circ}$. There was no paradox of the jugular venous or arterial pulses. The liver was moderately enlarged and there was slight sacral œdema.

The urine showed 30 to $100 \mathrm{mg}$. albumin. Microscopy showed many red and white cells and large numbers of granular and hyaline casts. Hæmoglobin 10.5 g./100 ml., PCV 33 per cent, WBC 17,600 with 84 per cent polymorphs, ESR $95 \mathrm{~mm}$. in one hour (Westergren). Chest radiograph (Fig. 7) showed pulmonary cedema, a right pleural effusion, and gross enlargement of the heart. The electrocardiogram (Fig 8) showed slight ST depression, and the T waves were fairly deeply inverted in the left ventricular leads. Plasma proteins showed a moderate reduction in albumin and slightly raised $\alpha_{2}$ and $\gamma$-globulins. Blood urea initially was $90 \mathrm{mg} . / 100 \mathrm{ml}$. and subsequently reached a peak of $294 \mathrm{mg} . / 100 \mathrm{ml}$. Serial serum electrolytes showed low sodium and chloride with progressively rising potassium. Cold agglutinans, ASO titre, Coombs' test, and C-reactive protein were all normal or negative. Repeated sputum cultures were negative. No cytopathic agent was cultured from the throat or fæces, but the serum showed a neutralizing antibody titre against Coxsackie B2 of 1 in 128 on November 1, 1962. On November 13 the titre was 1 in 256 and on August 6, 19631 in 512.

This patient, who was desperately ill, was treated with digoxin, omnopon, oxygen by intermittent positive pressure using the Bird Machine, salt and fluid restriction. Erythromycin was given parenterally. He became very disorientated and had to be restrained. The jugular venous pressure rose to very high levels and 48 hours after admission a venesection of $500 \mathrm{ml}$. of blood was performed. This produced very little clinical improvement and subsequently he had severe oliguria and the serum potassium rose progressively to a maximum figure of $6.8 \mathrm{mEq} / \mathrm{litre}$. He was then having a high carbohydrate intake, resonium and insulin. Fortunately a diuresis started shortly afterwards, his

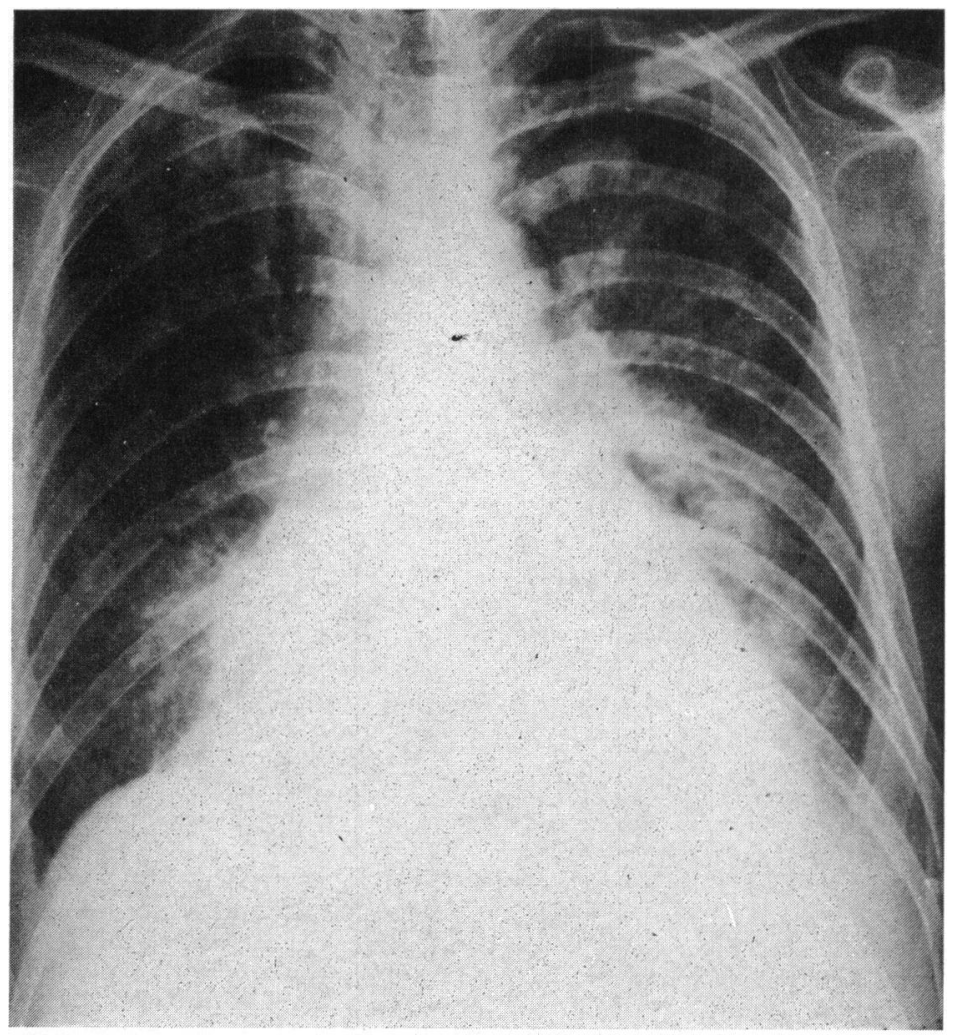

FIG. 7.-Chest radiograph of Case 7 showing large heart shadow and pulmonary œdema. 


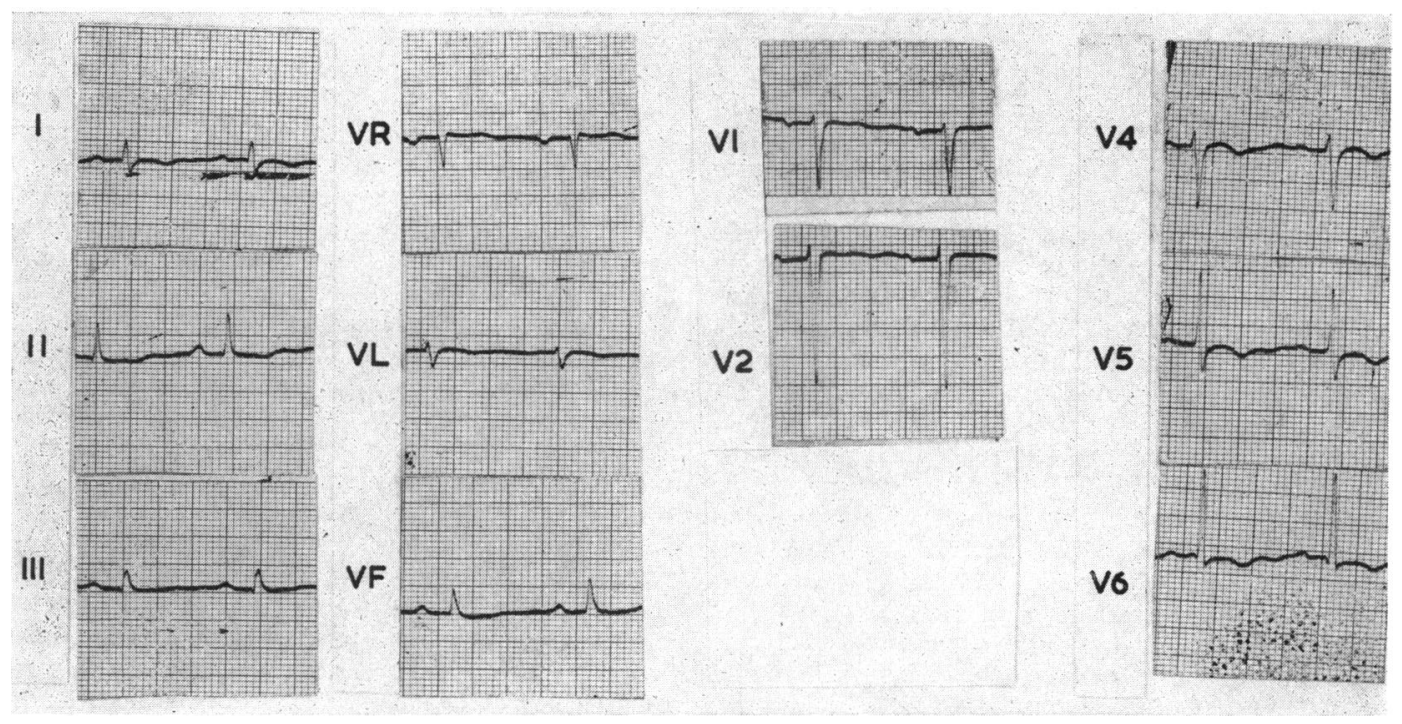

FIG. 8.-Electrocardiogram (November 3) of Case 7 showing $T$ wave inversion.

condition rapidly improved, and his urine returned to normal. His hæmoglobin on November 14, 1962 was $8.9 \mathrm{~g} . / 100 \mathrm{ml}$., and he was then given two pints of packed cells. Serial cardiograms showed slight worsening of the appearances noted initially, but his chest radiograph (Fig. 9) and his cardiogram (Fig. 10) were both normal on discharge home on December 16. When seen as an out-patient in February 1963 he was extremely well and had resumed work. At his last visit in August 1964 his electrocardiogram and chest radiograph were again normal, and he had remained entirely well.

Summary. A 30-year-old man was admitted with a three-week history of an influenza-like illness. Twentyfour hours before admission he became very breathless and on admission was desperately ill. He had marked enlargement of the heart, pulmonary œdema, and heart failure. There was no evidence of pericarditis at any stage. The urine showed many blood cells and casts, suggesting an associated nephritis, and his extreme mental confusion may have resulted from encephalitis. A significant neutralizing antibody titre against Coxsackie B2 was obtained. After a stormy illness, he made a complete recovery over a two-month period.

Case 8. A housewife, 30 years old, was admitted to the Sir Charles Gairdner Hospital on December 3, 1962 with fever and right pleuritic pain of two days' duration. She also complained of stiffness of the neck and pain in the right shoulder. There was no history of sore throat, skin rash, or abdominal pain, and she had previously been well apart from occasional bouts of mental depression.

On admission her general condition was good and she did not appear seriously ill. Her temperature was $38^{\circ} \mathrm{C}$. She had considerable right pleuritic pain, but no pleural or pericardial rub was heard. The air entry was slightly reduced over the right lower lobe and a few basal crepitations were audible in this area. Heart, blood pressure, and pulses were normal. The urine was negative. Hæmoglobin 13.2 g./100 ml., white cells 12,000/c.mm., polymorphs 90 per cent, ESR $37 \mathrm{~mm}$. in one hour (Westergren). Chest radiograph (Fig. 11) showed appearances suggesting a posterior loculated pleural effusion, possibly associated with pneumonitis. The left lung and diaphragm were normal. The heart was normal in size and shape. Serial radiographs showed gradual reduction of the right-sided opacity. The initial electrocardiogram (Fig. 12) showed sinus tachycardia (130 a minute) which persisted for about two weeks. There was slight ST depression and $T$ wave inversion in leads II, III, IIIR, and VF. In subsequent records the $T$ waves were also inverted in leads $V 2,3,4,5$, and 6 , and this præcordial $T$ wave inversion varied considerably from tracing to tracing, though in general the changes tended to improve. No cytopathic agent was obtained from the throat or fæces. A neutralizing antibody titre against Coxsackie B1 of 1 in 256 was present on December 7. Thirteen days later the titre was 1 in 128. The antibody titres to other $B$ viruses were less than 1 in 10, and antibody tests against influenza, adenovirus, and para-influenza virus were all negative.

With symptomatic treatment the pleuritic pain gradually disappeared and her condition on discharge home three weeks after admission was satisfactory. She was readmitted six weeks later on February 6, 1963 because of a 24-hour period of left pleural pain. She felt feverish and ill, and her temperature was $38^{\circ} \mathrm{C}$. The air entry and percussion were slightly impaired over the 


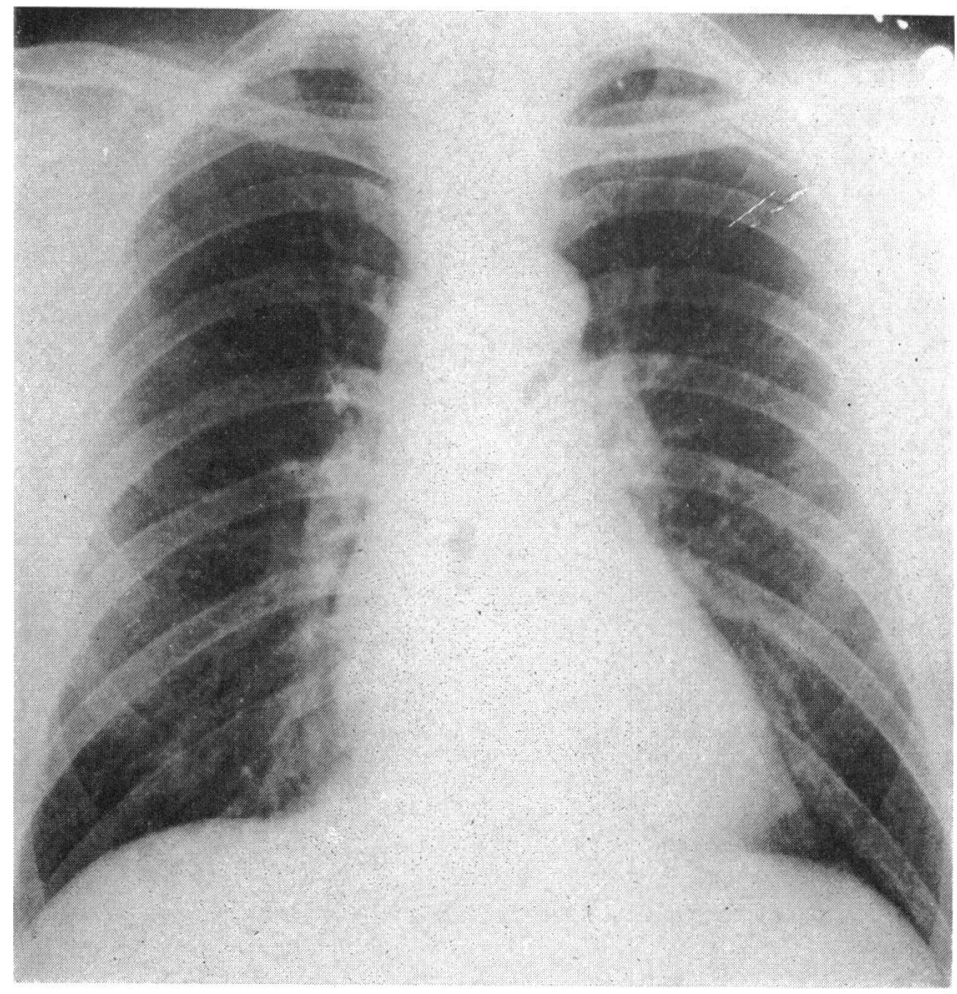

FIG. 9. Chest radiograph of Case 7 (now normal).

FIG. 10.-Electrocardiogram (December 28) of Case 7 (now normal) 


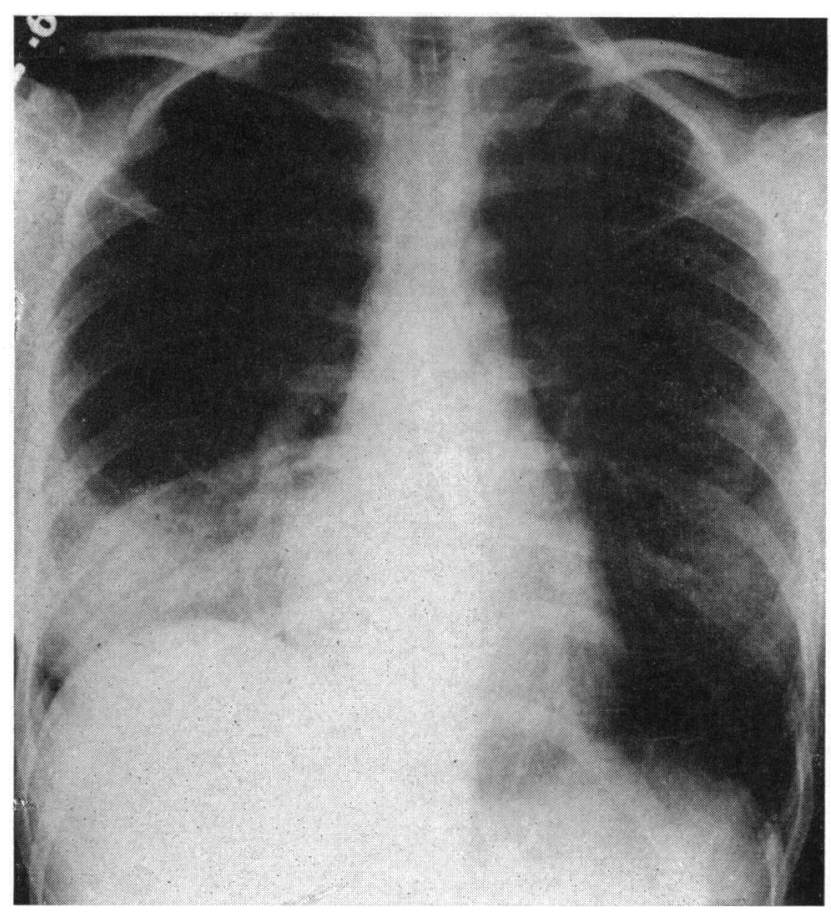

FIG. 11.-Chest radiograph of Case 8 showing loculated pleural effusion and pneumonitis.

right lower lobe, but there were no definite clinical signs on the left side. Hæmoglobin $12.6 \mathrm{~g} . / 100 \mathrm{ml}$., WBC $11,700 /$ c.mm. with 86 per cent polymorphs. ESR 28 mm. in one hour (Westergren). Several LE cell preparations were negative. Serum electrophoresis showed slightly raised $\gamma$-globulin and slightly reduced albumin levels. Serum transaminase (SGOT) 12 units (February 22). The Coxsackie B1 titre was now 1 in 32. Chest radiograph showed slight tenting of both diaphragms with further clearing of the posterior basal

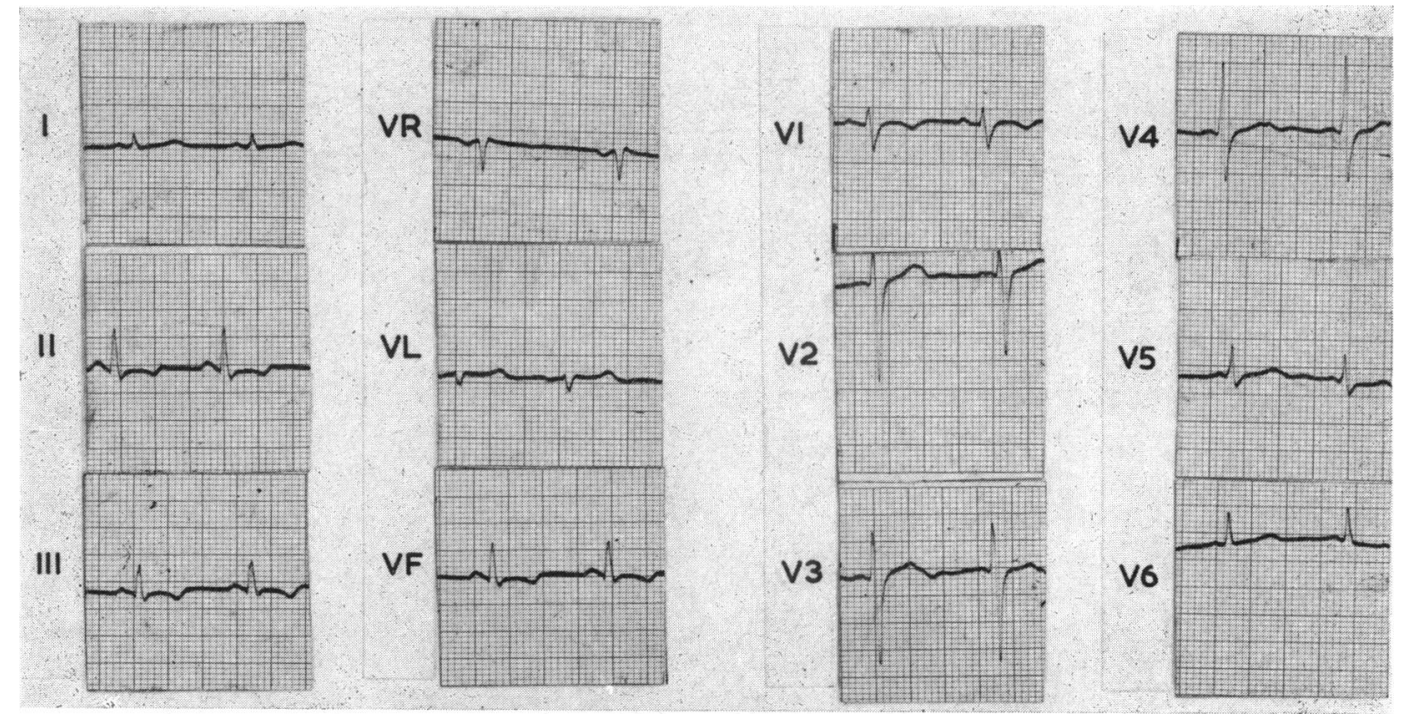

FIG. 12.-Electrocardiogram (December 12, 1962) of Case 8, showing $T$ wave inversion in posterior lead. 


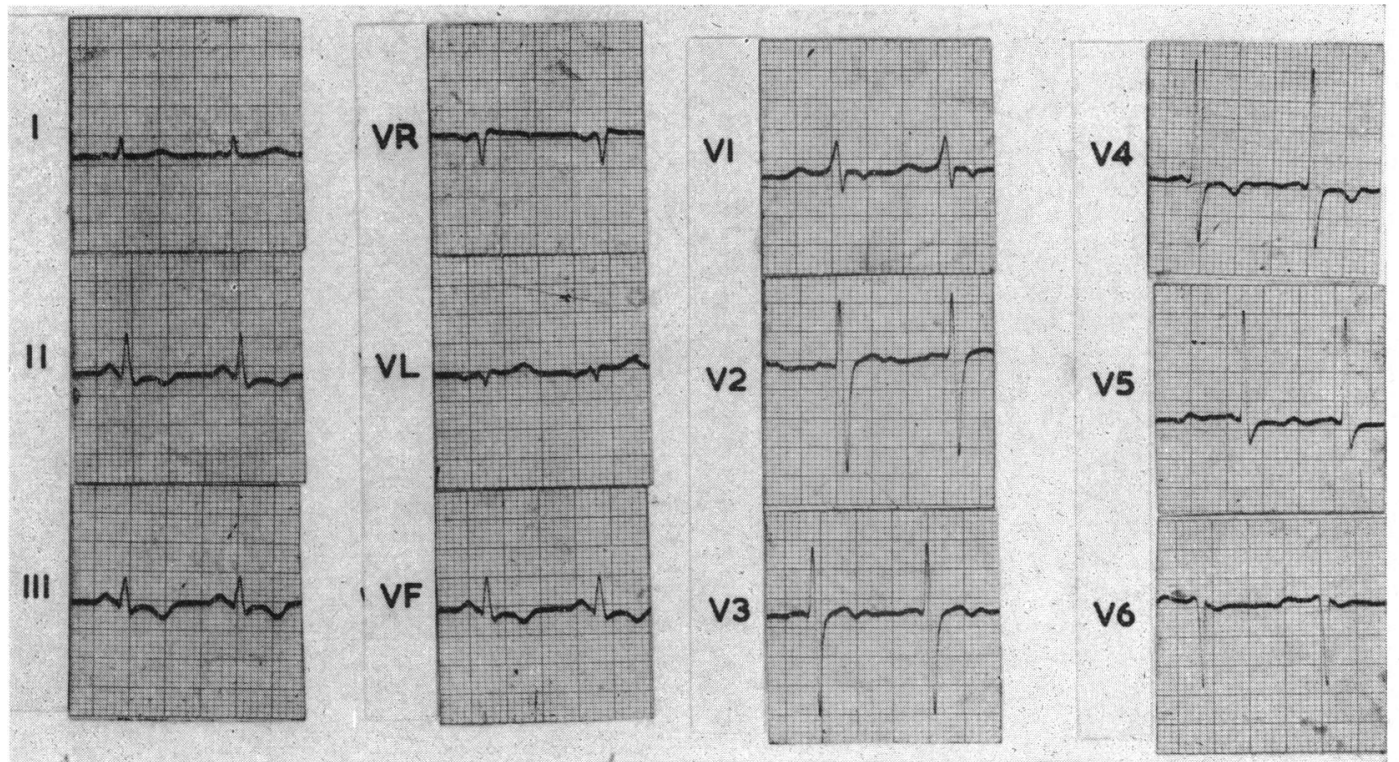

FIG. 13.-Electrocardiogram (May 16, 1963) of Case 8, showing residual $T$ wave inversion in posterior leads and V2 and V3.

opacity in the right side, and fresh slight shadowing at the left compatible with a pleural reaction. The heart shadow now appeared slightly enlarged compared with the previous chest films. A repeat cardiogram (Fig. 13) showed that the ST-T changes in the posterior leads were again more marked than on the previous tracing and again there was well-marked $T$ wave inversion in leads V2 and V3. On February 28 the $T$ waves were upright in leads II and V2, 3, and 4, and the ST depression in leads III and VF was less marked. She was again treated symptomatically with bed-rest and aspirin. She remained well, apart from one slight exacerbation of left chest pain. The ESR fell to $17 \mathrm{~mm}$. in one hour (Westergren). No pericardial rub or heart murmurs were heard at any stage and her condition on discharge home on February 28 was satisfactory.

A third admission was requested on May 15, because of marked pain and swelling of the left leg of 24 hours' duration. She had no chest symptoms. The heart and lungs were clinically normal. There was now an obvious left femoral vein thrombosis. The chest radiograph showed minimal tenting of the right diaphragm and the electrocardiogram again showed increased ST-T changes in leads III, IIIR, and VF, and the $T$ wave was again inverted in V2 and V3. Blood count was normal and ESR was $8 \mathrm{~mm}$. in one hour. She was treated with anticoagulants and an elastic stocking and was discharged home six days after admission. Her leg progressively improved, and when last seen in June 1964 she was well and had no swelling of the left leg. There had been no recurrence of her chest symptoms. Chest radiograph was negative apart from slight tenting of the right diaphragm. An electrocardiogram (Fig. 14) was still abnormal and showed persistent ST-T changes in leads II, III, and VF. The T waves in the præcordial leads were upright. There was no clinical or radiographic abnormality of the heart.

Summary. A 30-year-old woman was admitted with fever and right-sided pleurisy. The initial cardiogram was abnormal and showed ST depression and $T$ wave inversion in the posterior leads with rather variable $\mathbf{T}$ wave inversion in leads V2-4. A fairly high titre against Coxsackie B1 was obtained. Her symptoms and radiograph improved, but the cardiogram remained abnormal. Six weeks later she had left-sided pleurisy. Eighteen months after the initial illness the electrocardiogram was still abnormal, though there was no clinical abnormality of the heart or lungs. It appears that this patient, with classical Bornholm disease, had a silent myocarditis with possible permanent myocardial damage. The lack of hæmoptysis and the nature of the electrocardiographic changes made pulmonary infarction unlikely.

Case 9. A farmer, then aged 27 years, was medically examined in 1954 for insurance purposes and was said to be entirely healthy. A few weeks later he developed a pyrexial illness with generalized muscle pains. Two months after the onset of this illness he was found to have mitral incompetence and atrial fibrillation. In late 1962 he became aware of slowly progressive effort dyspnoa. Two weeks before his first admission to the Sir Charles Gairdner Hospital on June 24, 1963 he developed an influenzal illness similar to his illness in 1954. There was no history of sore throat, joint pains, chorea, or skin rash. On admission he was in good general condition and was apyrexial. He had well-marked mitral incompetence and the pansystolic mitral murmur was followed by a third sound and a short mitral diastolic murmur. 

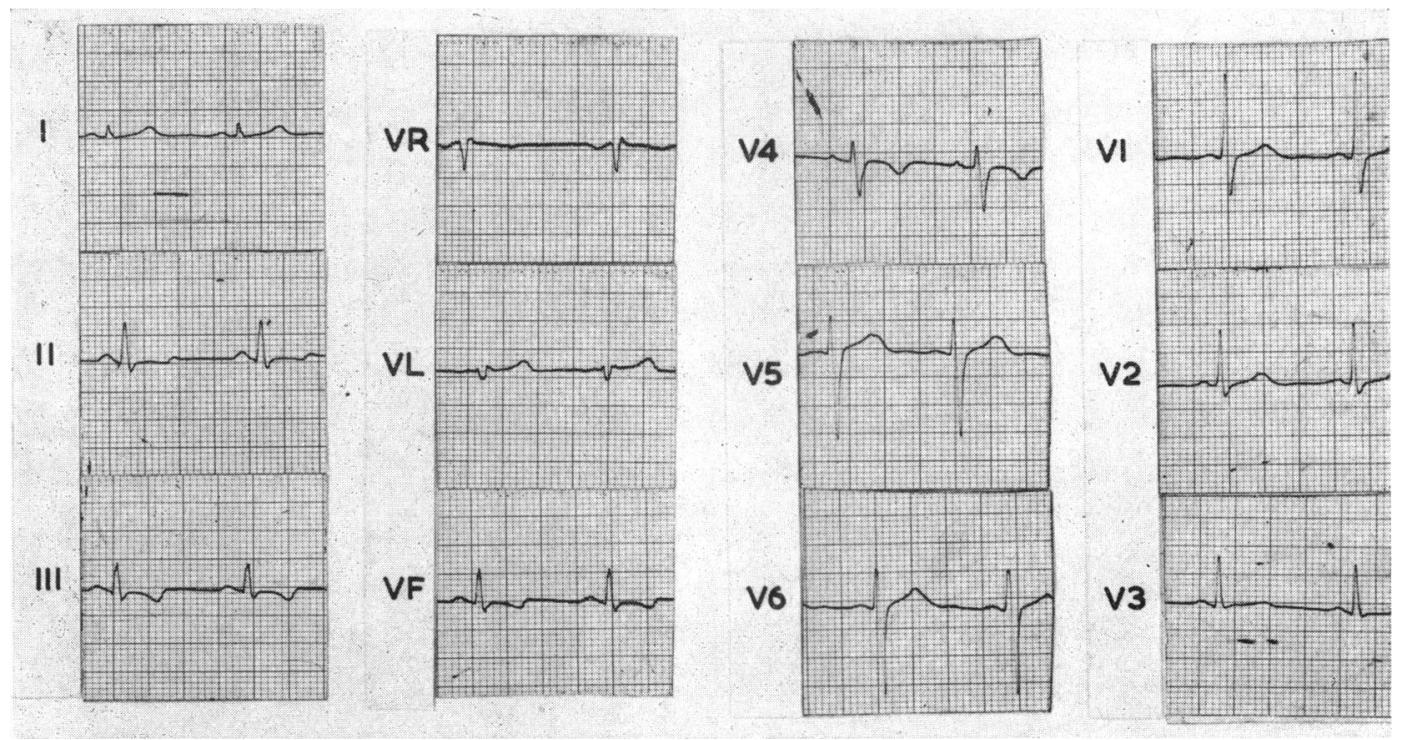

Fig. 14.-Electrocardiogram (June 2, 1964) of Case 8, showing persistent changes in posterior leads.

Blood pressure was $140 / 80 \mathrm{~mm}$. Hg. Atrial fibrillation was present with a rapid ventricular response. Blood count was normal. ESR $10 \mathrm{~mm}$. in one hour (Westergren). Blood cultures sterile. Chest radiograph showed moderate enlargement of left atrium and ventricle. There was moderate pulmonary venous congestion. A cardiogram showed normal axis, atrial fibrillation, left ventricular hypertrophy, and digitalis effect. A neutralizing antibody titre of 1 in 320 against Coxsackie B5 was present on June 25. The titre against the other $B$ viruses was less than 1 in 10 .

He was discharged on a suitable dose of digoxin. Readmission was requested two months later in August 1963, some three weeks following another influenza-like illness, after which he developed severe dyspnœa, nausea, and vomiting. On admission he was obviously ill and orthopnœic. Temperature $38^{\circ} \mathrm{C}$. Jugular venous pressure was very high and showed systolic pulsation. The liver was grossly enlarged, pulsatile, and tender. The pulses were small and extremities cold. Blood pressure $120 / 90 \mathrm{~mm}$. Hg without paradox. Mitral incompetence was present as before, and there was now, in addition, an easily palpable right ventricle and a loud pulmonary component of the second sound. There was no peripheral œdema, but widespread crepitations were present throughout both lungs and a fairly large right pleural effusion was present. Urine examination was negative. Blood urea $74 \mathrm{mg} . / 100 \mathrm{ml}$. Hæmoglobin 16.6 g./100 ml., WBC $11,100 /$ c.mm. with 77 per cent polymorphs, 6 per cent eosinophils, ESR $1 \mathrm{~mm}$. in one hour (Westergren). Plasma proteins, ASO titre, C-reactive protein, sputum, and electrolytes were all normal or negative. The electrocardiogram now showed marked right axis deviation with atrial fibrillation, left ventricular hypertrophy, and digitalis effect as before. Chest radiograph showed that the heart was much larger than at his previous admission. There was bilateral pulmonary congestion and a right pleural effusion. This effusion was straw coloured and contained 90 per cent of lymphocytes and $3 \mathrm{~g} . / 100 \mathrm{ml}$. of protein.

A neutralizing antibody titre of 1 in 320 against Coxsackie B4 was again present on August 23. The high titre remained unchanged in further blood samples taken 10 and 26 days later.

He was treated with fluid and sodium restriction, redigitalization, mercaptomerin, pleural aspiration, and venesection. Phenindione (dindevan) was given because of the possibility of pulmonary infarction. His progress was initially slow, but thereafter he made very satisfactory improvement. When seen as an out-patient on December 21, he felt well and had returned to work. He stated that his condition was then very similar to that before his most recent illness. Chest radiograph was similar to that of his first admission and repeat electrocardiogram showed that the right axis deviation was much less marked. He was seen again in September 1964, when he was well and working, and had no undue dyspnca except on running. The Coxsackie B4 antibody titre was 1 in 320 on June 5, 1 in 160 on August 21, and 1 in 160 on September 15.

Summary. A man, aged 27 years, was found to have mitral incompetence and atrial fibrillation soon after a pyrexial influenzal illness in 1954. Two similar "influenza-like" illnesses occurred in 1963, after the second of which he had severe congestive heart failure and pulmonary hypertension. A high titre against Coxsackie B4 was present, and this has persisted, so far, for 17 months. It is postulated that he initially had a Coxsackie virus myocarditis with permanent myocardial or endocardial damage, leading to atrial fibrillation and mitral incompetence. His two subsequent exacerbations 
of heart disease following "influenza-like" illness in the nine years since the initial illness may have resulted from an exacerbation of virus-induced myocarditis.

Case 10. A medical practitioner, aged 45 years, was admitted to Sir Charles Gairdner Hospital on October 15, 1963 with a two-week history of tiredness, sweating, pyrexia as high as $39^{\circ} \mathrm{C}$., slight confusion, and toxæmia. He had a non-productive distressing cough and severe generalized muscle pains. He stated that he had had two previous episodes of pyrexia and muscle pains since 1961. He complained of slowly progressing effort dyspncea over the previous two years and had been treated for a cardiac infarction in 1961, and for hypertension since 1960 . There was no history of chest pain suggestive of angina at any time.

On admission he was ill and breathless. Temperature $37 \cdot 2^{\circ} \mathrm{C}$. Pulse 110 a minute. Blood pressure $110 / 90$ mm. Hg. There was gross left ventricular enlargement. A loud third sound was audible at the mitral area, but there were no heart murmurs, pericardial or pleural rubs. Jugular venous pressure was elevated $4 \mathrm{~cm}$. above the sternal angle with the patient at $80^{\circ}$. There was no paradox of arterial or venous pulses. The liver was $3 \mathrm{~cm}$. enlarged below the right costal margin and the spleen tip was palpable. There was no œdema. Small nodes were present in both axilla.

Full blood count was normal. ESR $2 \mathrm{~mm}$. in one hour (Westergren). Repeated urine testing was negative. Plasma proteins and electrophoresis, routine agglutinans, urinary catecholamines, LE cell preparations, ASO titre, C-reactive protein, serum electrolytes, and blood urea were all normal or negative. Chest radiograph showed much enlargement of the left ventricle and associated pulmonary congestion. Electrocardiogram showed left bundle-branch block and sinus rhythm. No cytopathic agent was isolated from the throat or fæces. On October 16 the blood sample showed a neutralizing antibody titre against Coxsackie B4 of 1 in 640. There was also a raised titre against Coxsackie B2 of 1 in 40 . The titres against the other Coxsackie $B$ viruses were less than 1 in 10. On October 31 the titre against Coxsackie B4 was unchanged, while that against B2 had increased to 1 in 160 .

He was treated with digoxin, oral diuretics, bed-rest, and aspirin. Slight intermittent pyrexia persisted for most of his two-week stay in hospital.

On discharge home he was ambulant, but his effort tolerance was poor. He was readmitted five weeks later in severe circulatory failure and died shortly afterwards while being given oxygen and pressor agents. Unfortunately a necropsy was not performed.

Summary. A 45-year-old man had been treated for a presumed cardiac infarction two years before his penultimate admission. Two weeks before admission he developed a pyrexial "influenza-like" illness, followed by rapidly progressive dyspnœa. There was marked enlargement of the left ventricle and triple rhythm, but no heart murmurs or rubs were audible. A high titre against Coxsackie B4 was found, and there was no change 14 days later, probably indicating an infection of some duration. There was, however, a fourfold increase in titre against Coxsackie B2 suggesting recent infection with this virus. The patient died suddenly five weeks after discharge from hospital. It is postulated that this patient may have had a Coxsackie myocarditis, superimposed on coronary heart disease.

\section{Discussion}

There seems no real doubt that Coxsackie B viruses were responsible for the heart disease in 7 of the above 10 adult patients. There is fairly good inferential evidence that the virus was responsible for chronic myocardial or endocardial damage in two others. The tenth patient's fatal illness has been attributed to the complementary effects of the virus on pre-existing coronary heart disease.

Diagnosis. The best means of diagnosis is the isolation of the virus from the throat, stool, or pericardial or pleural cavity, together with a progressive rise of the type-specific neutralizing antibody titre. Unfortunately, by the time the patient presents with heart symptoms, the acute stage of viræmia is usually over, and attempts at isolation of the virus may be unsuccessful. In practice, the diagnosis is made by the combination of the clinical picture, chest radiograph, electrocardiogram, and a rise in the serum neutralizing antibodies. Most patients with the acute illness will have fever and a raised ESR and a slight or moderate neutrophil leucocytosis. If pericarditis is present, the character of the chest pain and its relation to posture, respiration, and movement is often diagnostic of pericarditis, and this type of pain was present in the first six patients in this series. The chest radiograph may show a normal heart shadow (Case 2) or alternatively the heart shadow may be greatly enlarged (Case 1). Pleural effusion with or without pneumonitis may be associated with the heart disease (Case 8). The electrocardiogram may show typical widespread ST elevation in patients with acute pericarditis (Case 2). Non-specific $\mathrm{T}$ wave inversion is present in myocarditis, or in the later stages of myo-pericarditis.

The patient may show associated suggestive clinical features such as pleurisy, orchitis, myalgia, or aseptic meningitis. Another important diagnostic clue may be obtained from a history of "influenza" in other family members (Cases 1,2, and 5). Myocardial infarction may be difficult to differentiate from a Coxsackie myo-pericarditis. The serum transaminase (SGOT) level cannot be relied on as a raised value may be found in myocarditis as shown by Coltman (1962) in influenza myocarditis. Case 2 in this series had a raised SGOT level which also emphasizes the associated myocarditis in such a patient with clinical pericarditis. 
The serum neutralizing antibodies are type specific in the human and often persist for months or years after the initial infection (Case 9). This persistent rise can sometimes provide important retrospective evidence of previous infection. A rising titre, which is often fourfold in paired blood samples at 14 to 21 days' interval, indicates recent infection. It is important to note, however, that a raised titre can be found as early as 3 days after the clinical onset of illness (Rhodes and van Rooyen, 1962). The height of titre bears no relationship to the severity of the illness.

Experimental Evidence. Myocarditis has been produced in experimental animals, such as mice, hamsters, and guinea-pigs following inoculation of live Coxsackie $B$ viruses isolated from the myocardium, lung, or liver of human patients. In neonatal myocarditis, the virus can usually be isolated from the myocardium and frequently from other tissues, such as the liver and kidney. In adults it is still uncertain whether the acute heart lesion is due to a direct attack by the virus or a hypersensitivity phenomenon similar to that now believed to be the common denominator in such conditions as rheumatic fever, post-cardiotomy syndrome, post-myocardial infarction syndrome, and trauma to the chest wall ( $\mathcal{~}$. Amer. med. Ass., 1962). The latter explanation is suggested by the delay between the initial viræmia and the onset of the heart disease. The recurrent exacerbations in chronic Coxsackie myocarditis and pericarditis sometimes seen after repeated respiratory tract infections are best explained by such a theory (Cases 6 and 9). Anti-heart antibodies have been demonstrated in rheumatic fever, post-cardiotomy syndrome, myocardial infarction, and some cases of idiopathic cardiomyopathy (Sanders, 1963). It is generally conceded, however, that these could well be the effects of injury rather than the cause. It should also be noted that experimental heart lesions are not produced by homologous antigen injections, though this could well be explained by the fact that an infectious agent plus homologous antigen, plus an adjuvant, may be necessary to initiate the cardiac lesion. Important evidence in favour of the autoimmune theory is that bound $\gamma$-globulin has been demonstrated in the myocardium of patients with rheumatic heart disease (Kaplan and Dallenbach, 1961).

In their study of 1,042 patients with myocarditis, Gore and Saphir (1947) could make no ætiological diagnosis in 75 per cent. The microscopical appearances which they describe in "nonspecific myocarditis" are very similar to those described by Fiedler in 1899, and to those reported in fatal cases of Coxsackie myocarditis. It should now be possible to prove a virus ætiology in many such patients, and the numbers of "idiopathic" myocarditis should rapidly decline.

Relation to Permanent Heart Damage. The relation of Coxsackie infection to chronic or permanent heart damage is not yet clear. Godfrey (1951) and Wolff (1943) have reported cardiac enlargement and cardiographic changes persisting $2 \frac{1}{2}$ and 13 years respectively after an initial "acute benign pericarditis". There are also on record a few patients who have developed a true constrictive pericarditis following an episode of acute Coxsackie pericarditis (Wolff and Grunfeld, 1963). Similarly unexplained heart valve lesions often loosely attributed to rheumatic carditis may be of viral origin. Burch and De Pasquale (1964) point out that virus endocarditis is now known to occur in animals and may well be a cause of valve lesions in the human. In Case 9 of this series, the evidence strongly suggests that an initial virus myocarditis was responsible for persisting left ventricular damage with functional mitral incompetence or possibly organic mitral incompetence due to viral endocarditis. Two subsequent exacerbations of the heart disease followed influenza-like illnesses that were associated with a high titre against Coxsackie B4. Case 8 has residual electrocardiographic abnormalities 18 months after her initial illness. At the present time, she has no clinical heart disease, but prolonged follow-up will be of great interest. It is not unreasonable to suggest that some of the so-called idiopathic cardiomyopathies including the familial variety may be a late effect of the ravages of the Coxsackie virus.

Summation with Pre-existing Heart Disease. Another factor, about which little is known, is the effect of Coxsackie myo-pericarditis in a patient with pre-existing heart disease, such as coronary heart disease, hypertension, or endocarditis. By the laws of chance this is bound to happen occasionally, and one would hardly be surprised by the severity of the illness or the likelihood of incomplete recovery. In Case 10, there is suggestive evidence that the patient's fatal illness was due to a combination of Coxsackie myocarditis superimposed on pre-existing coronary heart disease.

Prognosis. Mention has been made of possible chronic pericardial, myocardial, and even endocardial damage and summation with pre-existing heart disease. Hæmopericardium has been reported in "acute benign pericarditis", especially if anticoagulants have been used (Swan, 1960). 
Arrhythmias have also been reported (Bradley, 1964). Recurrences are always possible, and Case 6 had four recurrences of pericarditis in the two years after the initial illness. Despite these frequent attacks of pericarditis, there is as yet no evidence of permanent heart damage in this patient, but prolonged follow-up will be necessary with particular reference to the development of constrictive pericarditis.

Treatment. Treatment of these potentially severe, and sometimes fatal, conditions is mainly symptomatic. Steroids may be considered, but it is important to note that there is some experimental evidence in adult mice that steroids, given in the acute phase of the illness, will greatly hasten the progress of the myocarditis (Kilbourne, Wilson, and Perrier, 1956). Anticoagulants are dangerous in virus pericarditis as in other varieties of diffuse pericarditis (Smith, 1961), and are best strictly avoided.

Obviously further research and publication of case reports are necessary to provide the complete answer to this problem. A high index of suspicion is necessary, and it should be remembered that Coxsackie myocarditis with or without pericarditis is relatively common. It is by no means a disease of newborn infants, and will probably be found in a surprising proportion of both adults and pædiatric patients in hospital and general practice if diligently sought. Prolonged follow-up of such patients is necessary to delineate the natural history of the heart lesions.

\section{SUMMARY}

A series of 10 adult patients, believed to have heart disease due to Coxsackie $B$ virus infection, is reported. There were 9 men, aged 27 to 56 years, and 1 woman aged 30 years. All patients had evidence of myocardial involvement, and 6 , in addition, had pericarditis and presented with pericardial pain. In the majority of patients, the ESR was moderately raised, and the white count showed a moderate leucocytosis with a preponderance of neutrophil leucocytes. Serological tests implicated Coxsackies B5 in 4, B4 in 3, B2 in 3, and $B 1$ in one. Seven patients, including a patient who was desperately ill with heart failure and nephritis, made a complete clinical recovery, though one of these patients has residual changes in the electrocardiogram. A further patient had four recurrences of pericarditis in the two years after the initial illness, but so far shows no evidence of permanent heart damage. One patient has mitral incompetence due to chronic myocardial damage or possible endocarditis. One patient died, possibly due to a summation of Coxsackie myocarditis with coronary heart disease.

Heart complications of Coxsackie virus infections are probably fairly common and are by no means restricted to newborn infants, as early reports suggested. Youngish men appear to be specially susceptible. The heart disease may be associated with other features of Coxsackie infection such as myalgia, orchitis, pleurisy, aseptic meningitis, and rarely hepatitis, pancreatitis, encephalitis, and nephritis. Other members of the family may have had a recent "virus infection". The diagnosis is made on the basis of clinical picture, associated features such as orchitis, family illness, radiograph, and electrocardiogram, and virus antibody tests.

Myocarditis may occur alone, but pericarditis is almost always associated with a degree of myocarditis. Dilatation of the heart rather than pericardial effusion is probably the usual cause of rapid change in heart size. The syndrome of acute "nonspecific benign pericarditis"may stimulate cardiac infarction and is most often due to a Coxsackie $B$ virus. The correct diagnosis is, therefore, "acute Coxsackie myo-pericarditis".

Most of the recorded deaths are in newborn infants, and the great majority of adult patients with heart involvement recover completely. Recovery will depend on the degree of myocardial injury, the presence of underlying heart disease, complications such as hæmopericardium, and the unpredictable possibility of future recurrences which may occur within the first few years after the initial illness. In a few patients constrictive pericarditis, chronic heart enlargement, or electrocardiographic abnormality may remain.

Coxsackie virus infection should be considered in patients with acute myocarditis, idiopathic cardiomyopathy, "murmurless heart disease", Fiedler's myocarditis, and otherwise unexplained cardiographic changes. Coxsackie virus endocarditis is known to occur in animals and should be considered in the diagnosis of obscure valve lesions in man.

The exact mechanism of the heart disease in adults is not yet known. There is suggestive evidence that the virus may initiate an auto-immune reaction such as probably occurs in traumatic carditis, postmyocardial infarction syndrome, trauma to the chest wall, and after heart surgery.

I would like to acknowledge my gratitude to the following physicians, who have allowed me to see and describe their patients: Professor E. G. Saint, Dr. J. Calder, Dr. T. Cullity, Dr. C. Fortune, Dr. P. Hurst, Dr. R. Lefroy, Dr. J. Olden, and Dr. J. D. Woods. I am especially grateful to Drs. W. Laurie and J. D. G. Hobday of the Virus Reference Laboratory. 


\section{REFERENCES}

Aagaard, A. S., and Jensen, S. E. (1952). Epidemic nonspecific pericarditis. Nord. Med., 48, 1409.

Agranat, A. L. (1961). A near-fatal case of Coxsackie B1 myocarditis (with pericarditis) in an adult. $S$. Afr. med. F., 35, 831.

Bell, J. F., and Meis, A. (1959). Pericarditis in infection due to Coxsackie virus group B, type 3. New Engl. F. Med., 261, 126.

Bing, H. I. (1933). Epidemical pericarditis. Acta med. scand., $80,29$.

Bradley, E. C. (1964). Acute benign pericarditis. Amer. Heart F., 67, 121.

Burch, G. E., and De Pasquale, N. P. (1964). Editorial. Viral endocarditis. Amer. Heart f., 67, 721.

Christian, H. A. (1951). Nearly ten decades of interest in idiopathic pericarditis. Amer. Heart $\mathcal{F}$., 42, 645.

Coltman, C. A. (1962). Influenza myocarditis. F. Amer. med. Ass., 180, 204.

Creveld, S. van, and de Jager, H. (1956). Myocarditis in newborns caused by Coxsackie virus. Clinical and pathological data. Ann. padiat. (Basel), 187, 100.

Curnen, E. C., Shaw, E. W., and Melnick, J. L. (1949). Disease resembling nonparalytic poliomyelitis associated with a virus pathogenic for infant mice. F. Amer. med. Ass., 141, 894.

Dalldorf, G. (1949). The Coxsackie group of viruses. Science, 110, 594.

Fiedler, A. (1899). Ueber akute interstitielle myokarditis. In Festschrift zur Feier des Fünfzigjährigen Bestehens des Stradtkrankenhauses zu Dresden-Friedrichstadt, pt. 2, p. 3. Bdensch, Dresden.

Fletcher, E., and Brennan, C. F. (1957). Cardiac complications of Coxsackie-virus infection. Lancet, 1, 913.

$\longrightarrow$, and - (1958). Cardiac complications of Coxsackievirus infection. Lancet, 2, 585.

Glajchen, D. (1961). Myocarditis due to Coxsackie virus infection in an adult. Brit. med. $\mathcal{F} ., 2,870$.

Godfrey, J. (1951). Myocardial involvement in acute nonspecific pericarditis: A report of 3 cases. Ann. intern. Med., 35, 1336.

Gore, I., and Saphir, O. (1947). Myocarditis-A classification of 1402 cases. Amer. Heart F., 34, 827.

Hosier, D. M., and Newton, W. A. (1958). Serious Coxsackie infection in infants and children. A.M.A. F. Dis. Child., 96, 251.

f. Amer. med. Ass. (1962). Editorial. Hypersensitivity-A common denominator in myocardial disease? 181, 784 .

Javett, S. N., Heymann, S., Mundel, B., Pepler, W. J., Lurie, H. I., Gear, J., Measroch, V., and Kirsch, Z. (1956). Myocarditis in the newborn infant-A study of an outbreak associated with Coxsackie group B virus infection in a maternity home in Johannesburg. $\mathcal{f}$. Pediat., 48, 1.
Johnson, R. T., Portnoy, B., Rogers, N. G., and Buescher, E. L. (1961). Acute benign pericarditis. Arch. intern. Med., 108, 823.

Kaplan, M. H., and Dallenbach, F. D. (1961). Immunologic studies of heart tissue. III. Occurrence of bound gamma globulin in auricular appendages from rheumatic hearts. Relationship to certain histopathologic features of rheumatic heart disease. $\mathcal{f}$. exp. Med., 113, 1.

Kilbourne, E. D. (1950). Diverse manifestations of infection with a strain of Coxsackie virus. Fed. Proc., 9, 581.

-, Wilson, G. B., and Perrier, D. (1956). The induction of gross myocardial lesions by a Coxsackie (pleurodynia) virus and cortisone. F. clin. Invest., 35, 362 .

Lane, A. J. (1961). Acute non-specific pericarditis associated with high titres to a Coxsackie group B4 virus. Proc. roy. Soc. Med., 54, 232.

Lewes, D., and Lane, W. F. (1961). Acute benign pericarditis due to Coxsackie virus group B, type 3. Lancet, 2, 1385.

Montgomery, J., Gear, J., Prinsloo, F. R., Kahn, M., and Kirsch, Z. G. (1955). Myocarditis of the newborn. S. Afr. med. F., 29, 608.

Movitt, E. R., Lennette, E. H., Mangum, J. F., Berk, M., and Bowman, M. S. (1958). Acute benign pericarditis-A report of 2 cases associated with group $\mathbf{A}$ and group $\mathbf{B}$ Coxsackie viruses. New Engl. F. Med., 258, 1082.

Null, F. C., and Castle, C. H. (1959). Adult pericarditis and myocarditis due to Coxsackie virus, group B, type 5 . New Engl. 7. Med., 261, 937.

Pollen, R. H. (1963). Myocarditis due to Coxsackie virus, group B, type 5. Amer. F. Cardiol., 12, 736.

Rhodes, A. J., and van Rooyen, C. E. (1962). Text Book of Virology, 4th ed. Williams and Wilkins, Baltimore.

Sanders, V. (1963). Viral myocarditis. Amer. Heart f., 66, 707.

Smith, W. G. (1961). "Postcardiotomy syndrome", anticoagulants, and hæmopericardium. Lancet, 1, 750.

Swan, W. G. A. (1960). Acute non-specific pericarditis. Brit. Heart f., 22, 651.

Swann, N. H. (1961). Epidemic pleurodynia, orchitis, and myocarditis in an adult due to Coxsackie virus, group B, type 4. Ann. intern. Med., 54, 1008.

Weinstein, S. B. (1957). Acute benign pericarditis associated with Coxsackie virus group B, type 5. New Engl. f. Med., 257, 265.

Wolff, L. (1943). Acute pericarditis with special reference to changes in heart size. New Engl. F. Med., 229, 423.

- , and Grunfeld, O. (1963). Pericarditis. New Engl. F. Med., 268, 419.

Woodward, T. E., McCrumb, F. R., Carey, T. N., and Togo, Y. (1960). Viral and rickettsial causes of cardiac disease, including the Coxsackie virus etiology of pericarditis and myocarditis. Ann. intern. Med., 53, 1130. 